\title{
The Clemenceau debate and occupational health
}

\section{VIJAY KANHERE}

Occupational Health and Safety Centre, Gokuldas Pasta Road, Neelkant Apts, Dadar (E), Mumbai 400014 INDIA email:vijaykanhere@gmail.com

The proposal to permit the dismantling of the French ship Clemenceau, containing several tonnes of asbestos and other toxic material, led to a lot of discussion in the media. The discussion centred on the pros and cons of permitting the import of hazardous waste from developed countries despite international treaties forbidding this practice.

Some press reports focussed on the health risks faced by workers who did not have proper protection while dismantling ships. Others expressed concern that if India refused to accept the ship for demolition, it would result in a loss of jobs at the Alang shipbreaking yard in Gujarat, which is already facing bad times. Press reports also noted that workers who developed asbestosis while working at the Ahmedabad Electricity Company were fighting for justice $(1,2,3)$.

Asbestos is known to cause cancer and asbestosis. One reason why dismantling the Clemenceau would have been much cheaper in India is that the ship-breaking industry here offers no protection to workers from the short-term and long-term risks of this hazardous process.

The Clemenceau turned back before it reached Indian shores. But the problem has not gone away. The heated discussions have provided an opportunity to consider the subject of occupational health in India and related ethical issues of concern to medical practitioners and researchers.

A number of studies in India have estimated the prevalence of asbestosis in this country. The studies find that 23-70 per cent of people with direct exposure to asbestos for more than 20 years will develop asbestosis (4). An estimated 6,000 workers in India meet these conditions, as well as some 100,000 workers indirectly exposed to asbestos (5). But as of 2006, only 30 workers have been compensated for occupation-related asbestosis (4). Surely many more workers at the Alang ship-breaking yard alone have had long-term exposure to asbestos $(5,6)$.

A similar situation prevails in terms of other occupational health problems. To take just one instance, high noise levels at the workplace are reported in textiles, jute, steam generation, compressors and engineering industries, among others. In one survey, some of us at the Occupational Health and Safety Centre (OHSC) checked more than 1,000 workers exposed to high noise levels at the workplace, with complaints about problems of hearing. We diagnosed 396 workers from Mumbai, Amritsar and Ahmedabad as suffering from occupational noise-induced hearing loss.

However, in most industries, few of the affected people are diagnosed, let alone compensated. According to calculations made more than a decade ago, two million new cases of occupational disease occur each year (7). At the time, the ministry of labour had reported 1,624 work-related deaths. Reporting is poor and the real figure would have been closer to 150,000. Legal mechanisms for compensation exist in the form of the Workmen's Compensation Act and the Employees State Insurance Act, enacted in 1923 and 1948 respectively. But there is no legislation covering the majority of workers in the unorganised sector.

\section{Affected people are not informed of study results}

Many epidemiological studies demonstrate the impact of noise, dust and other occupational health problems. These have been cited by the director of the National Institute of Occupational Health, an ICMR institution, in various orientation courses for doctors on occupational health organised by our organisation. For example, studies by the National Institute of Occupational Health (NIOH), Ahmedabad, found that 11 per cent of workers in asbestos mines and nine per cent of workers in asbestos textile mills had asbestosis. Thirty-eight per cent of workers in agate polishing units had silicosis and 30 per cent of workers in the blow rooms of cotton textile units had byssinosis. But the workers were not informed about the results of the study, nor were affected workers informed of the diagnoses.

In another instance, workers in a glass factory pressured the state government to ask the $\mathrm{NIOH}$ to provide examinations. As a result, individual workers diagnosed with silicosis were given their medical reports. However, there was no accompanying evaluation of their resultant disability, which is needed to pursue claims with the Employees' State Insurance Corporation (ESIC) (8).

The doctors involved in such studies must inform workers about the individual and collective findings. It is the ethical duty of researchers of occupational illness to inform those who are affected by such illnesses of their condition, and to provide certification 
so that they can exercise their right to treatment and compensation. This needs to be specifically mentioned as a duty of researchers in ethical guidelines for research in health.

We must remember that doctors who choose to specialise in occupational health are also employed by industries. Industry is not interested in recording instances of occupational diseases. This creates a conflict between the doctor's loyalty to an employer and the duty to provide proper diagnosis and treatment, report occupational illness so that preventive steps can be taken, and provide documentation for compensation claims. The duty to the patient must be paramount.

\section{The Employees' State Insurance Scheme}

It was only in 1997 that doctors in the ESIS first diagnosed hearing loss due to noise among workers. The diagnosis of occupational hearing impairment is relatively straightforward, yet workers struggling for justice face immense problems.

About 8 million employees and their families are covered by the ESIS. For all these employees there are only four occupational disease centres all over India. In my experience - confirmed in discussions with other doctors in Kolkata and Mumbai - these centres are ill-equipped and the doctors are not well-informed. Not a single audiometer is available for testing hearing loss in the entire ESIS system in the industrialised states of Maharashtra and West Bengal. One hospital in West Bengal asked for an audiometer and an ENT specialist. It was allotted on ENT specialist but no audiometer.

According to an ESIC document titled 'Notes on occupational diseases', "There is no characteristic audiogram" of noise-induced hearing loss (9). In reality, reference books are very clear about the typical audiogram of a person suffering from noise-induced hearing loss (10). The ESIC document indicates either deliberate unethical misdirection or ignorance. It is unethical in both cases because these notes were meant for doctors treating workers. Secondly, doctors who are treating workers have themselves not acquired correct information. Why does this situation exist even with a problem that is comparatively straightforward to diagnose? Another problem is misdiagnosis. A number of studies have found that patients with byssinosis, silicosis, asbestosis and occupational pneumoconiosis are thought to have tuberculosis (11).

\section{Medical education and occupational health}

Occupational health is a low priority in the medical education syllabus, listed as part of the undervalued preventive and social medicine category. It is unfortunately not a priority, not for the government and not for medical education institutions. Nor is there much interest in other occupation-related illnesses, such as skin diseases, that are caused by extensive exposure to various chemicals. Does this situation prevail because treating occupational problems of poor workers is not profitable for medical professionals? If this is true, it opens up new areas of enquiry into the ethical aspects of the practice of medicine.

The public discussion on Clemenceau posed a conflict between workers' health and jobs. This is not a real conflict. We must work to improve the ethical fabric of medical education, practice and research so as to protect people's health as well as their jobs.

\section{References}

1. Jain Sonu, Jain Rupam. How asbestos firms brush cancer, disease under industry carpet. Indian Express. 2006 Jan 7 [cited 2006 Mar 5]. Available from: http://www.indianexpress.com/res/web/ple/archive_full_story.php?content_id=85479

2. Agarwal Ravi. Asbestos, a demon of the past.Indian Express. 2006 Jan 17 [cited Mar 5]. Available from: http://www.indianexpress.com/archive_full_story. php?content_id=86041

3. Mabut Pierre. French government forced to recall ship laden with toxic waste. World Socialist Web Site 2006 Feb 22 [cited 2006 Mar 20 ]. Available from: http://www.wsws.org/articles/2006/feb2006/ship-f22.shtml

4. Murlidhar V, Kanhere V. Asbestosis in an asbestos composite mill at Mumbai: a prevalence study. Environmental Health: A Global Access Science Source 2005 [serial on the Internet]. 2005 Oct [cited 2006 Mar 20]; 4 (24). Available from: http:///www.ehjournal.net/content/4/1/24

5. Sharma D. Indian groups demand ban on asbestos. Lancet 2002, 359: 1414.

6. International Commission on Occupational Health. Asbestos and public health: the international dimension. Proceedings of a seminar at the London School of Hygiene and Tropical Medicine. 2001 Jun 5 [cited 2006 Mar 20]. Available from: http://www.icoh.org.sg/news/asbestos.html

7. Smith Stirling. Occupational safety and health in India: an attempt to estimate the real number of work related deaths. [monograph on the Internet]. 1999 Nov [cited 2006 Mar 20]. Available from: http://www.raqsmediacollective.net/globalvillage/work/h38b.htmf

8. Society for Participatory Research in Asia. Story of workers' struggle on compensation for silicosis. New Delhi: PRIA;1992.

9. Chandar Satish, Dayal B. Brief notes on occupational diseases. New Delhi: ESIC; 1990.

10. Sataloff J, Sataloff ST, Vassallo LA. Hearing loss. 2nd ed. Philadelphia: JB Lippincott Co; 1980.

11. Nemery B. Occupational respiratory disease. NatI Med J India 1995; 8: 199-201 